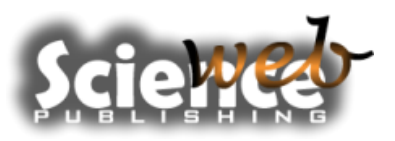

\title{
The impact of external debt on the Nigerian economy
}

\author{
Onyeiwu Charles* • Oladipopo Abimbola
}

Department of Banking and Finance, Faculty of Business Administration, University of Lagos, Nigeria.

*Corresponding author. E-mail: chasonyeiwu@yahoo.com.

Accepted $11^{\text {th }}$ July, 2018.

\begin{abstract}
This study examined the effect of external debt on economic growth in Nigeria. Gross domestic product was used as a proxy for economic growth which is the dependent variable while external debt stock, external debt service payments, domestic debt, external reserve and exchange rate were the independent variables. External debt stock and external debt service payments were used to capture the external debt burden in Nigeria. The paper adopted the ARDL bound testing to co-integration as an appropriate technique. The result shows that domestic debt lag 1, D(LDDS (-1)), has a negative but significant effect on economic growth. The result of the conditional error correction regression suggests that external debts stock lag 1, that is, LEDS (-1) has a significant direct relationship with economic growth at 1 percent significance level. It could also be observed that external debt service payment and exchange rate indicate a significant negative effect on economic growth while external reserve reveals a significant positive impact on economic growth in the long run. The consequent policy recommendation is that external debts should be contracted solely for economic reasons and not for social or political reasons. When government is increasing her spending based on external debt, it has to be meticulous about the sector of the economy where the loan is channeled. Increase in government spending centered on agriculture, manufacturing, entrepreneurship, human capital development and technological innovation will definitely stimulate economic growth and enhance the pace of development. While increase in government spending on the non-productive sector (current consumption) of the economy from external loan will spontaneously crowd out private saving and investment and may depress the economy.
\end{abstract}

Keywords: External debt, dual gap theory, gross domestic product, ARD.

\section{INTRODUCTION}

There is a general appreciation that economic growth is a primary goal of all countries and it is expected that such growth should translate to improved standard of living and better welfare for the citizenry which must be sustained for such country to make a meaningful stride towards economic development. A critical prerequisite for such growth is a massive investment in capital formation which would include physical capital, financial capital, human capital and effective information technology facilities. The limiting factor however is that no single country has all the savings domestically to actualize the required capital investment. Furthermore, because no country has all inputs required for economic transformation, a lot of the inputs in form of machines, technology, management and organization have to be acquired from external sources which have to be paid for in foreign currency. The shortage of foreign currency as a result of inadequate export capacity and deficient domestic saving capacity is often cited as justification for external borrowing. This shortage in domestic savings and foreign exchange requirement for capital formation is sometimes referred to as the 'dual-gap thesis'. This dual gap is more acute in sub-Saharan Africa countries where Nigeria belongs. However, savings and foreign exchange import is not without cost. Many countries resort to debt when non debt creating finance such as direct foreign 
investment, international development assistance and portfolio investments and unrequited transfers are not readily available in the required amount. The problem is that external debt today has to be repaid with interest in the future and if not properly invested could be a burden for future generation. Nigeria for instance, has suffered in the past from debt burden and debt servicing problem leading to debt rescheduling and proposition of different debt management options which more or less were face saving measures, a problem from which it was delivered from when the Paris Club agreed to write off $60 \%$ of the $\$ 30.85$ billion (amounting to $\$ 18$ billion) owed to its club members. This deal was signed in July 2005 , after which the country was able to offset the balance of $40 \%$, thus, saving the country from the yearly $\$ 2.3$ billion debt service burden. Since then the external debt exposure has been increasing. For instance, in 2004, Nigerian external debt stock was about $\$ 39.90$ billion but by 2006 it has been reduced to $\$ 9.6$ billion but by 2011 , it has risen to $\$ 17.70$ billion and by 2014 , it had shut up to $\$ 24.75$ billion and in 2016, the debt stock had become $\$ 31.16$ billion (index mundi, 2017). The continuous rise in external debt may have a deleterious effect on economic welfare of citizens if not checked as it is required that massively larger amount of naira be earned for every dollar that is to be repaid in the future unlike the situation in the past. Every depreciation of the naira puts additional strain on future income for debt that has been spent. It is important that Nigerian government and other government that accumulate external debt to appreciate that such debt can easily become a burden on the economy, weakening its foundation as accumulating debt also means accumulating risks by increasing claims on unrealized future income. In view of the above, the objective of this paper is to ascertain the impact of external (foreign) debt on the Nigeria economy and development.

\section{LITERATURE REVIEW}

\section{Review of conceptual and definitional issues}

Arnone et al. (2005) defines external debt as that portion of a country's debt that is acquired from foreign sources such as foreign corporations, government or financial institutions. According to Ogbeifun (2007), external debt arises as a result of the gap between domestic savings and investment. As the gap widens, debt accumulates and this makes the country to continually borrow increasing amounts in order to stay afloat. He further defined Nigeria's external debt as the debt owed by the public and private sectors of the Nigerian economy to non-residents and citizens that is payable in foreign currency, goods and services. Debt crisis occurs when a country has accumulated a huge amount of debt such that it can no longer effectively manage the debt which leads to several mishaps in the domestic political economy (Adejuwon et al., 2010).

Debts are classified into two i.e productive debt and dead weight debt. When a loan is obtained to enable the state or nation to purchase some sort of assets, the debt is said to be productive e.g. money borrowed for acquiring factories, electricity, and refineries etc. However, debt undertaking to finance war and expenses on current expenditure are dead weight debt. These two types of debt however require that the borrower's futures saving must cover the interest and principal payment (Debt Servicing). Therefore, debt financed investment need to be productive and well managed enough to earn a rate of return higher than the cost of debt servicing.

\section{An overview of trends in relevant macroeconomic variables}

It is important to examine if indeed Nigeria's public debt is near unsustainable level. Or is it that there are triggers of sovereign debt problem which have begun to manifest in the country's fiscal management? Policy makers should not dismiss either of the propositions without examining them.

Figure 1 shows the trends of External Debt Service Payments since 35 years ago (1980 to 2015) and also shows that the payment history has not been constant. From 1980 to 1985 there was continuous improvement in the payment till 1986 when the payment dropped by about $7 \%$ and in 1987 it dropped further by about $40 \%$ which may be due to the new government and inconsistency in policy implementation during that period. Between 1988 and 1990 there was continuous increase in payment and from that period till 2004 there was no much improvement in the external debt service payment in the country. In year 2005, the payment increased by about $70 \%$ and there was significant payment in 2014 but there has been a reduction due to several factors such as marginal improvement in government revenue, high inflation rate, inadequate export capacity and change in government among others.

Figure 2 explains the trend in Nigerian External Debt Stock. The external debt stock in Nigeria has shown a stable but rising trend which peaked in 2004 and then declined sharply in 2006. External debt stock had about 90\% reduction around 2006 and ever since that period there has not been any significant increase in the external stock of debt in the country until the last quarter of 2017 when there was a remarkable increase (Figure 2).

Figure 3 displays the exchange rate in Nigeria for the past 35 years. The exchange rate in Nigeria over the years has been deteriorating and seldom recovered for any length of time for the period covered. From 1980 to 1991, there was no significant change in the exchange rate. But from 1992 till date the exchange rate has been 


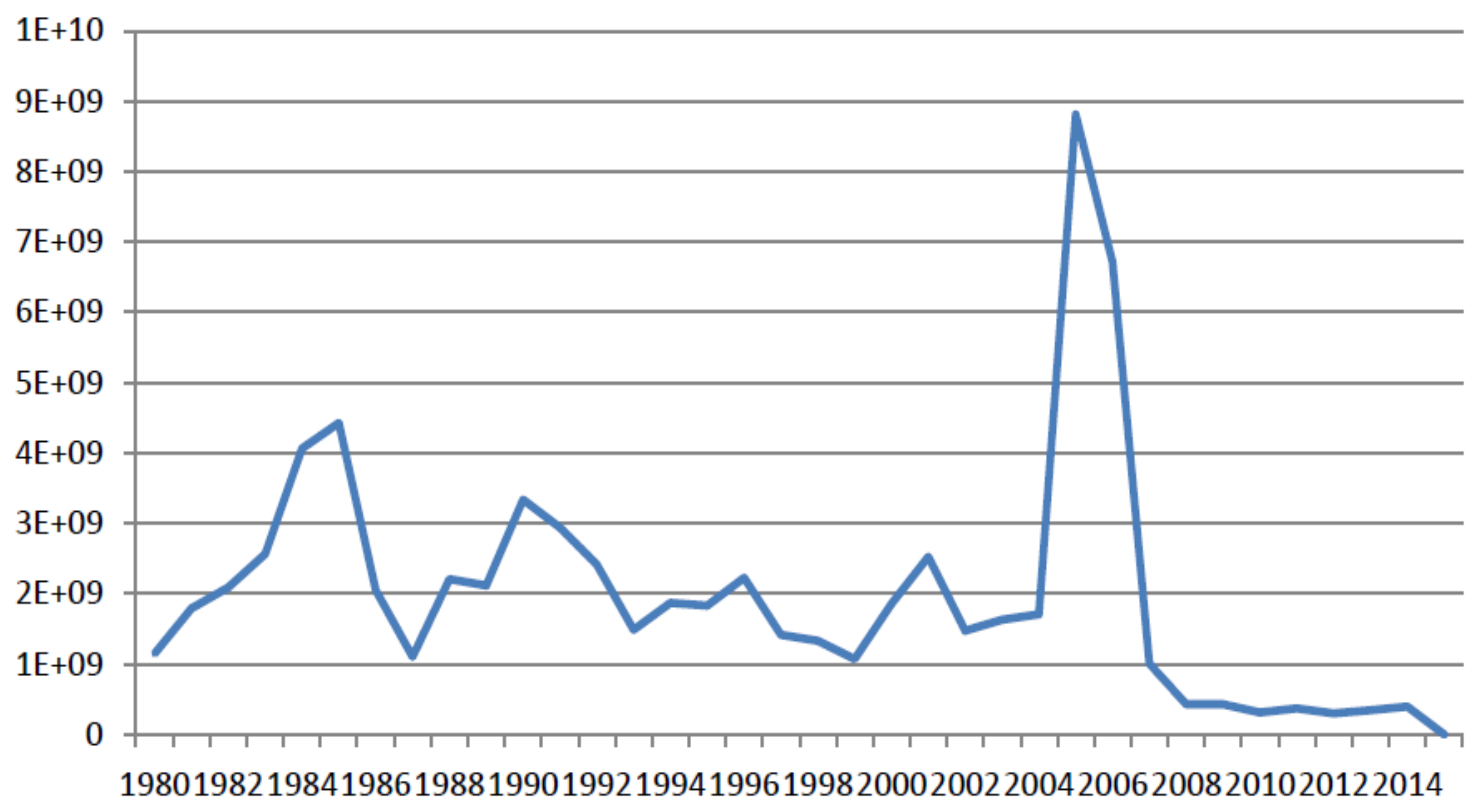

Figure 1. Trends of external debt services payments in Nigeria from 1980 to 2015. Source: CBN statistical bulletin 2015.

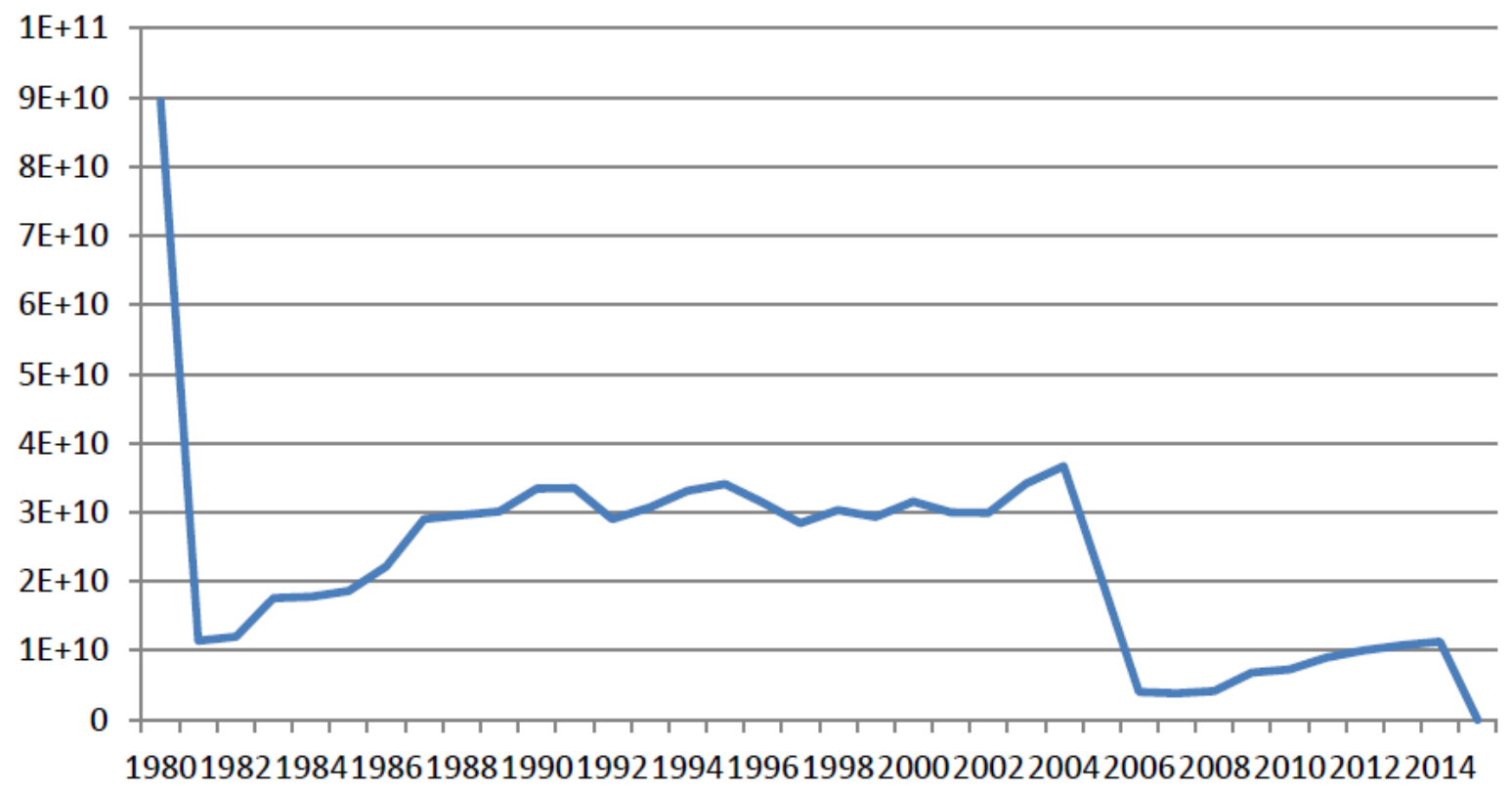

Figure 2. Trends of external debt stock in Nigeria from 1980 to 2015. Source: CBN statistical bulletin 2015.

changing significantly albeit a negative one from a national interest perspective. These vagaries are as a result of frequent changes in government policies as pertaining to exchange rate management in Nigeria, crude oil price volatility and the mono economy status of the Nigerian state. This continuous deterioration in exchange rate portents grave consequences on Nigeria's ability to service its expanding debt stock which is increasingly tending towards the commercial instead of the concessionary end of the loans market.

\section{Review of theoretical issues}

Several theoretical contributions have been made as regards the subject matter of external debt and economic growth. These theories are of relevance to this paper as they serve as a building block to this work and as such 


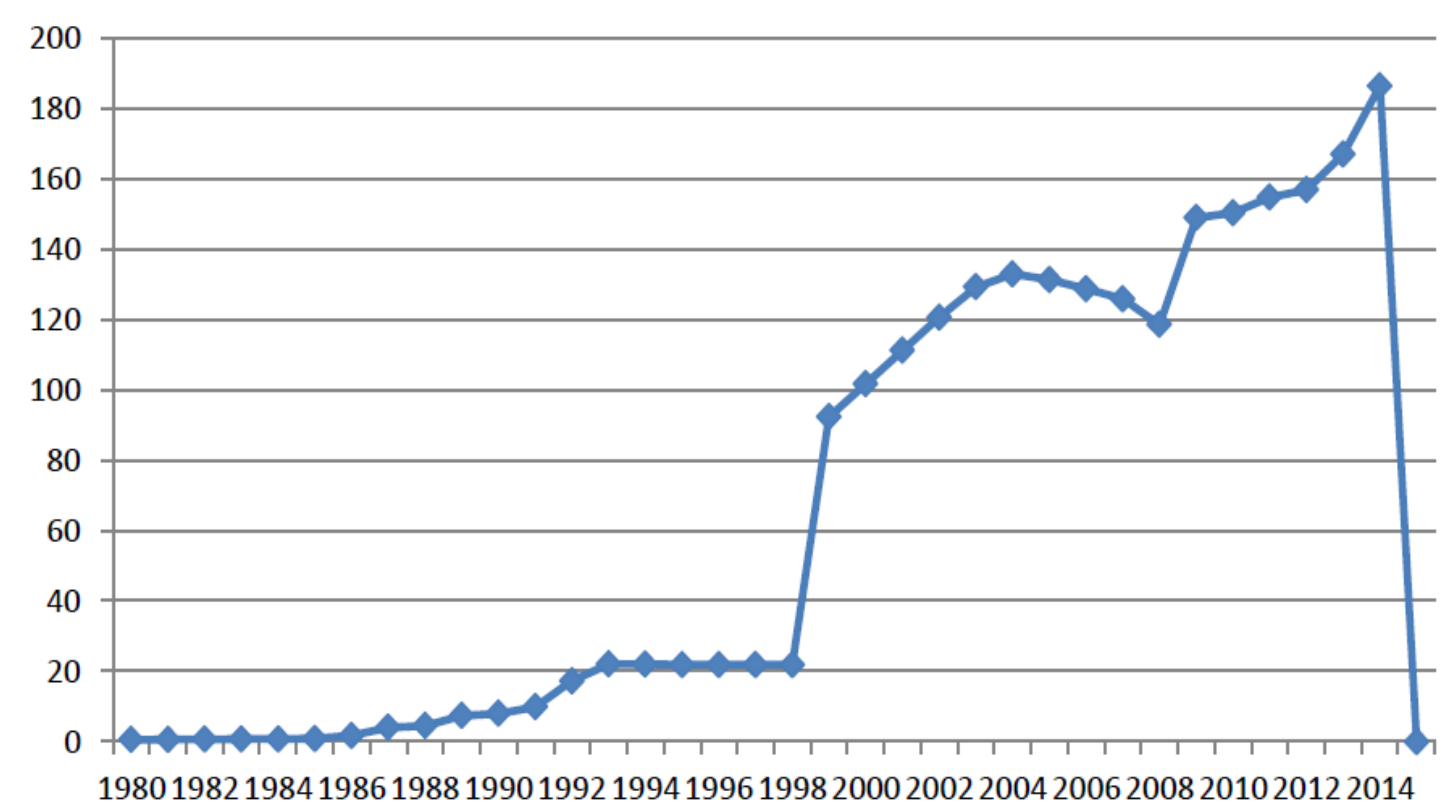

Figure 3. Trends in Nigeria exchange rate from 1980 to 2015. Source: CBN statistical bulletin 2015.

the following theories will be discussed; the dual-gap theory, Solow growth model, Keynesian theory and dependency theory.

\section{Dual-gap theory}

Omoruyi (2005) stated that most economies experience shortfall in form of gap between the level of savings and investment and have resorted to external borrowing in order to fill this gap. This gap provides the motive behind external debt as pointed out by Chenery and Strout (1966) which is to make up for the shortage of savings and investment in a nation as increases in savings and investment would lead to increase in economic growth (Hunt, 2007). The dual-gap analysis provides a framework that shows that the development of any nation is a function of investment and that such investment requires domestic savings which is not sufficient to ensure that development take place (Oloyede, 2002). Besides the inadequacy of savings in the domestic economy for the required minimum investment which should result into planned growth rate, there is the second gap that arises because of the shortfall in foreign exchange earnings which is required to import the foreign components of development inputs.

\section{Dependency theory}

The dependency theory seeks to outline the factors that have contributed to the development of the underdeveloped countries. This theory is based on the assumption that resources flow from a "periphery" of poor and underdeveloped states to a "core" of wealthy states thereby enriching the latter at the expense of the former. The phenomenon associated with the dependency theory is that poor states are impoverished while rich ones are enriched by the way poor states are integrated into the world system (Todaro, 2003; Amin, 1976).

Dependency theory states that the poverty of the countries in the periphery is not because they are not integrated or fully integrated into the world system as is often argued by free market economists, but because of how they are integrated into the system. From this standpoint a common school of thought is the bourgeoisie scholars. To them the state of underdevelopment and the constant dependence of less developed countries on developed countries is as a result of their domestic mishaps. They believe this issue can be explained by their lack of close integration, diffusion of capital, low level of technology, poor institutional framework, bad leadership, corruption, mismanagement, etc. (Momoh and Hundeyin, 1999). They see the underdevelopment and dependency of the third world countries as being internally inflicted rather than externally afflicted. To this school of thought, a way out of the problem is for third world countries to seek foreign assistance in terms of aid, loan, investment, etc. and allow undisrupted operations of the Multinational Corporations (MNCs). Due to the underdeveloped nature of most LDC's, they are dependent on the developed nations for virtually everything ranging from technology, aid, technical assistance, to culture, etc. The dependent position of most underdeveloped countries has made them vulnerable to the products of the Western metropolitan countries and Breton Woods institutions (Ajayi, 2000). The dependency theory gives a detailed account of the 
factors responsible for the position of the developing countries and their constant and continuous reliance on external assistance for their economic growth and development.

\section{Solow growth model and external debt}

The Solow growth model is built on a closed economy which makes use of labour and capital as its means of production. Under this condition, external debt affect economic growth through its effect on the domestic saving which in turn is used as investment in a closed model. The general effect of external debt on the Solow growth model can be analyzed by looking at the individual effects of the debt overhang and debt crowding theories on the Solow growth model. According to the debt overhang theory, in order for the government to service accumulated debt, it will increase tax rate on the private sector which will discourage private sector investment and reduce government expenditure on infrastructure as the resources are used to pay up huge debt service payments instead of being put into investment. This will lead to a reduction of total (private and public) investment in the economy and a shift downward of both the investment and production function curves in Solow growth model. On the other hand in the case of debt crowding out, in a bid to clear their outstanding debts, countries use their revenue from export earnings and in some cases resources including foreign aid and other foreign exchange resources are used to service debt. Those countries which transfer revenue from export earnings which it could have used for investment in the economy to avoid huge debt payment arrears will discourage public investment causing a decline in growth rate and will shift both the investment and production function curves in Solow growth model downward (Dereje, 2013).

\section{Keynesian theory}

There are a number of economic theories but the Keynesian theory patterning to government intervention to forester economic growth was considered the most appropriate. The theory recognizes the possibility of market failure, existence of externalities and lumpiness of some investments which must of necessity elicit government intervention because the private sector in most times is profit motivated, risk averse and short term focused and therefore may not always be relied upon to respond effectively to ensure that the economy continues to grow. Therefore, monetary and fiscal policy action of government is required to direct the economy. These actions will bring about stability in output over the business cycles. Keynes (1964) stated that during depression, a combination of two approaches must be applied viz: a reduction in interest rate (monetary policy), and government investment in infrastructure (fiscal policy). Both Keynesians and monetarists believe that both fiscal and monetary policies affect aggregate demand (Blinder, 2008). The monetary policy requires CBN to reduce interest rate to commercial banks that will in turn do the same to their customers. Government investment in infrastructure injects fund into the economy by creating business opportunities, employment and demand. One of the sources of fund for infrastructural development is external borrowing during fiscal deficit. This implies that Keynesian theory which views capital accumulation as a catalyst to economic growth seem to support external loans as it injects fund into the economy to increase economic activity resulting in growth.

\section{Empirical evidences}

The motive behind external debt is to boost economic growth and development of any nation but as a result of future high debt service payments, it poses a serious threat to the economy of that nation. Economic researchers have therefore sought out to investigate the implication of external debt burden on the economies of debtor nations and have come up with diverse views.

In a comparative study conducted by Ayadi and Ayadi (2008) on the impact of external debt on economic growth of Nigeria and South Africa using both Ordinary Least Square (OLS) and Generalized Least Square (GLS), they found evidence for a negative relationship between external debt and economic growth in both countries. However, South Africa is better than Nigeria in managing her debt service. In addition, external debt contributes positively to growth up to a point after which its contribution becomes negative in Nigeria (reflecting the presence of non-linearity effects).

Adesola (2009) examined the relationship between debt servicing and economic growth in Nigeria, using the ordinary least square multiple regression approach. His result showed that debt payments to the London club creditors, Paris club creditors, Promissory notes holders and other creditors have significant impact on the GDP and GFCF (Gross Fixed Capital Formation), while debt payments to Paris club and debt payment to Promissory notes holders are positively related to GFCF and GDP. The debt payments to London club creditors and other creditors revealed a negative effect on GFCF and GDP for the period of 1981-2004.

Akran (2011) in the study of the impact of public debt on economic growth and investment in Pakistan developed a hybrid model that explicitly incorporates the role of public debt in growth equations. He adopted the Autoregressive distributed lag (ARDL) technique in estimating the model and the result revealed that both domestic and external debt have negative relationship with per capita GDP and investment, confirming the 
existence of "Debt overhang effect" which crowds out private investment.

Safadari and Mehirizi (2011) investigated the effect of external debt on economic growth in Iran for the period of 1974-2007, by observing the balance and long term relation of five variables: GDP, Private investment, Public Investment, external debt and Imports. They employed the Vector autoregressive model (VAR) in their econometric analysis and the result of the research showed that external debt and imports had a negative effect on gross domestic product, but variables of private and public investments had positive effects on economic growth.

In a related study conducted by Amassoma (2011) investigating the causal nexus between external debt, internal debt, and economic growth in Nigeria, employed the Granger causality test in determining the direction of causality of the variables. He found that there exist a bidirectional causal relationship between internal debt and economic growth, while external debt and economic growth have a unidirectional causal relationship suggesting that economic growth causes external debt in Nigeria.

Uzun et al. (2012) determined the impact of external debt on economic growth in 19 Transitional economies adopting the panel autoregressive distributed lag (ARDL) model. It was found that external debt has positive impact on economic growth. Also openness of the economy has a positive impact in the long run, while external debt to export ratio has a negative impact on growth rate of the transitional economies in the short run.

Egbetunde (2012) in his study of causal relations tested for the stationary properties of variables and found them stationary at first difference, the result of the cointegration test showed the presence of long run relationship between Public debt and economic growth in Nigeria. The result of the study revealed that there exist a bi-directional relationship between public debt and economic growth, implying that improvement in economic activities call for borrowing to enhance on-going development processes in the economy, and borrowing also promotes growth in Nigeria. Similarly Rahman et al. (2012) in their study of relationship between external debt and gross domestic product in Bangladesh used annual time series data to avoid seasonal biases, and the ADF and Phillips-Perron test were carried out to ascertain the stationary properties of the variables, Granger causality and co-integration models were also employed to determine the Long run relationship as well as the direction of causality that exists between the variables, they found that there exist a bi-directional causal relationship between GDP and external debt.

\section{MATERIALS AND METHODS}

\section{Research design}

Conclusive research design was adopted for this paper; secondary data was used based on availability of data from Central Bank of Nigeria, Federal Office of Statistics and Debt Management Office. Data from 1981 to 2016 was used. The analysis of data was based on the use of non-parametric measure to analyse the relationship between external debt and other variables on Gross Domestic Product (GDP). The impact was ascertained by the use of the Least Square Estimation Technique which gives the best linear unbiased estimate. The reasons for choosing the Ordinary Least Square are many. Some which are:

- The parameters estimates are obtained by ordinary least square

- The computational procedure of ordinary least square is fairly simple as compared with other econometric techniques and the data requirements are not excessive.

- The least square method can be used in a wide range of economic relationship with fairly satisfactory result and despite the improvement of computational equipment and of statistical information which facilitated the use of other more elaborated econometric technique, it should be noted that ordinary least square is still one of the highly used or the most commonly used method in estimating relationship in economic models.

- Moreover, the mechanics of least square are simply to understand and the ordinary least square is an essential component of most other econometric techniques.

\section{Model specification and justification}

The main aim of this study is to investigate the effect of External Debt on Economic Growth in Nigeria. The model is adopted from a simple open macroeconomic debt growth model employed by Boboye and Ojo (2012). The model is specified of the functional form:

GDP $=f(E D S, D S P, E X R, D D S, E X T R)$

Where:

GDP $=$ Gross Domestic Product

EDS $=$ External Debt Stock

$\mathrm{DSP}=$ External Debt Service Payments

$E X R=$ Official Exchange Rate

DDS = Domestic Debt Stock

EXTR= External Reserve.

The model is specified of its stochastic form:

$\mathrm{GDP}_{\mathrm{t}}=\alpha 0+\alpha 1 \mathrm{EDS}_{\mathrm{t}}+\alpha 2 \mathrm{DSP}_{\mathrm{t}}+\alpha 3 \mathrm{EXR}_{\mathrm{t}}+\alpha 4 \mathrm{DDS}_{\mathrm{t}}+$ $\alpha 5$ EXTR ${ }_{t}+\mu_{t} \ldots \ldots \ldots \ldots . . . .(1)$

Where:

$\mu=$ Error term

\section{RESULTS}

The analysis of the descriptive statistics for the study 
Table 1. Descriptive statistics.

\begin{tabular}{lcccccc}
\hline Parameter & LGDP & LEDS & LDSP & LEXTR & LDDS & LEXR \\
\hline Mean & 15.05418 & 12.98523 & 10.46441 & 14.75348 & 13.08779 & 3.293778 \\
Median & 15.30334 & 13.34570 & 10.76877 & 15.07116 & 13.41151 & 3.811330 \\
Maximum & 18.44717 & 15.40276 & 13.96723 & 18.27108 & 16.21868 & 5.535333 \\
Minimum & 11.45450 & 7.754138 & 6.996079 & 8.340850 & 9.323008 & -0.494296 \\
Std. Dev. & 2.337323 & 1.932532 & 1.709893 & 3.164801 & 2.076758 & 1.947662 \\
Skewness & -0.150359 & -1.050327 & -0.257973 & -0.557401 & -0.276754 & -0.735479 \\
Kurtosis & 1.714215 & 3.407236 & 2.630222 & 2.161962 & 1.861818 & 2.202203 \\
& & & & & & \\
Jarque-Bera & 2.615513 & 6.867885 & 0.604403 & 2.917639 & 2.402743 & 4.200297 \\
Probability & 0.270426 & 0.032260 & 0.739189 & 0.232511 & 0.300781 & 0.122438 \\
& & & & & & \\
Sum & 541.9506 & 467.4683 & 376.7187 & 531.1253 & 471.1605 & 118.5760 \\
Sum Sq. Dev. & 191.2078 & 130.7138 & 102.3306 & 350.5588 & 150.9524 & 132.7685 \\
& & & & & & 36 \\
Observations & 36 & 36 & 36 & 36 & & 36 \\
\hline
\end{tabular}

Source: Authors computation with E-view 10.0, 2017.

Table 2. Stationarity result.

\begin{tabular}{lccc}
\hline Variables & Phillip Perron $($ PP) at levels & Philip Perron first difference & Order of integration \\
\hline LGDP & $3.410724(-2.948404)^{\star *}$ & $-3.891062^{* * *}(-2.951125)$ & $\mathrm{I}(0)$ \\
LEDS & $-1.526473(-2.948404)$ & $-3.194281^{* *}(-2.951125)$ & $\mathrm{I}(1)$ \\
LDSP & $-2.836417^{\star \star *}(-2.948404)$ & $-10.83602^{* * *}(-2.951125)$ & $\mathrm{I}(1)$ \\
LEXTR & $-1.142319(-2.948404)$ & $-3.669778^{* * *}(-2.951125)$ & $\mathrm{I}(1)$ \\
LDDS & $-17.21059^{* *}(-2.948404)^{\star * *}$ & $2.947427^{* *}(-2.954021)$ & $\mathrm{I}(0)$ \\
LEXR & $-0.087724^{\star *}(-2.948404)$ & $-3.411779^{* *}(-2.951125)$ & $\mathrm{I}(0)$ \\
\hline
\end{tabular}

Source: Computed by Author 2017. N/B: Stationary trend is achieved at PP values that are greater than the critical value in absolute terms; while ${ }^{*},{ }^{* *},{ }^{* *}$ indicate significance at $10 \%, 5 \%$ and $1 \%$ respectively. The values in parenthesis represent the critical value for the Philip Perron (PP) test at $5 \%$ level of significance.

indicates that the average growth for LGDP, LEDS, LDSP, LEXTR, LDDS, and LEXR was at 15.05, 12.99, $10.46,14.75,13.09$ and $3.29 \%$ respectively. The result suggests that economic growth (LGDP) and external reserve (LEXTR) portrays the highest average growth rate followed by domestic debt stock (Table 1). The standard deviation at 2.337, 1.933, 1.7099, 3.165, 2.0768 and 1.9477 were that of LGDP, LEDS, LDSP, LEXTR, LDDS, and LEX respectively. This further shows that the high standard deviation of LEXTR (3.165) and LGDP (2.337) suggests the degree of variability is much higher in external reserve and economic growth compared to the other variables. However, the Jarque-Bera normality test accepts the null hypothesis of a normally distributed series. This implies that the variables were normally distributed. The skewness for LGDP $(-0.150359)$, LEDS $(-1.050327)$, LDSP $(-0.2579)$, LEXTR $(-0.557401)$, LDDS (1.861818) and LEXR (-0.735479) indicate a negative skewness with relatively low values. All the variables indicate a kurtosis below 3.00 except for external debts service payment (LEDS) which further suggests the existence of frequent low deviations among the series.

From Table 2, it is observed that some of the variables (LEDS, LDSP and LEXTR) exhibit non-stationary characteristics at levels while others (LGDP, LEXR and LDDS) were stationary at 5 percent and 1 percent levels of significance. The non-stationary variables show that the presence of unit root cannot be rejected at 5 percent level. The null-hypothesis (there is unit root present for the variables at levels) is ascertained. Hence, for these series to be subjected to further analysis without the result being biased there is need for them to be differenced at first difference. Hence, the data nonstationary series were differenced once to achieve stationarity, indicating the series were all integrated to order 1.

Thus, it could be observed that there are a combination of variables that were integrated to order zero and 1 . This therefore implies that the use of Johansen and Juselius maximum likelihood cointegration approach would no longer be applicable since all the variables were not integrated of order 1 . The study therefore proceeds to 
Table 3. Bound testing co-integration result.

\begin{tabular}{lcccccc}
\hline \multicolumn{2}{c}{ F-Bounds test } & & \multicolumn{3}{c}{ Null hypothesis: } & No levels relationship \\
\cline { 1 - 2 } \cline { 5 - 6 } Test statistic & Value & & Signif. & I(0) & I(1) \\
\hline F-statistic & 4.407205 & & $10 \%$ & 1.81 & 2.93 \\
K & 5 & & $5 \%$ & 2.14 & 3.34 \\
& & & $2.5 \%$ & 2.44 & 3.71 \\
& & & $1 \%$ & 2.82 & 4.21 \\
\hline
\end{tabular}

Source: Authors computation with E-view 10.0, 2017.

Table 4. ARDL long run form and bounds test.

\begin{tabular}{|c|c|c|c|c|}
\hline \multicolumn{5}{|c|}{$\begin{array}{l}\text { Dependent variable: } \mathrm{D}(\mathrm{LGDP}) \\
\text { Conditional error correction regression }\end{array}$} \\
\hline Variable & Coefficient & Std. Error & $\mathrm{t}$-Statistic & Prob. \\
\hline $\operatorname{LGDP}(-1)^{*}$ & -0.708078 & 0.248394 & -2.850628 & 0.0215 \\
\hline LEDS(-1) & 0.189661 & 0.071015 & 2.670733 & 0.0283 \\
\hline $\operatorname{LDSP}(-1)$ & -0.218331 & 0.083001 & -2.630472 & 0.0302 \\
\hline $\operatorname{LEXTR}(-1)$ & 0.464206 & 0.126949 & 3.656624 & 0.0064 \\
\hline $\operatorname{LDDS}(-1)$ & 0.376606 & 0.292180 & 1.288953 & 0.2334 \\
\hline $\operatorname{LEXR}(-1)$ & -0.285129 & 0.086083 & -3.312252 & 0.0107 \\
\hline $\mathrm{D}($ LEDS $)$ & -0.161038 & 0.114022 & -1.412340 & 0.1955 \\
\hline $\mathrm{D}(\operatorname{LEDS}(-1))$ & -0.434216 & 0.127506 & -3.405454 & 0.0093 \\
\hline $\mathrm{D}(\operatorname{LEDS}(-2))$ & -0.197569 & 0.102421 & -1.928992 & 0.0899 \\
\hline $\mathrm{D}(\operatorname{LEDS}(-3))$ & 0.292323 & 0.098278 & 2.974446 & 0.0178 \\
\hline $\mathrm{D}($ LDSP $)$ & -0.075301 & 0.069840 & -1.078192 & 0.3124 \\
\hline $\mathrm{D}(\operatorname{LDSP}(-1))$ & -0.035794 & 0.091837 & -0.389751 & 0.7069 \\
\hline $\mathrm{D}(\operatorname{LDSP}(-2))$ & -0.175521 & 0.068162 & -2.575046 & 0.0329 \\
\hline $\mathrm{D}(\operatorname{LDSP}(-3))$ & -0.074565 & 0.041161 & -1.811527 & 0.1076 \\
\hline $\mathrm{D}($ LEXTR) & -0.035702 & 0.088064 & -0.405414 & 0.6958 \\
\hline $\mathrm{D}(\operatorname{LEXTR}(-1))$ & -0.261759 & 0.088838 & -2.946492 & 0.0185 \\
\hline $\mathrm{D}(\operatorname{LEXTR}(-2))$ & -0.256100 & 0.126694 & -2.021414 & 0.0779 \\
\hline $\mathrm{D}(\operatorname{LEXTR}(-3))$ & -0.261284 & 0.088076 & -2.966576 & 0.0180 \\
\hline $\mathrm{D}(\mathrm{LDDS})$ & -0.583987 & 0.234219 & -2.493343 & 0.0373 \\
\hline $\mathrm{D}(\operatorname{LDDS}(-1))$ & -0.233571 & 0.295724 & -0.789830 & 0.4524 \\
\hline $\mathrm{D}(\operatorname{LDDS}(-2))$ & -0.223486 & 0.174804 & -1.278491 & 0.2369 \\
\hline $\mathrm{D}($ LEXR) & 0.563283 & 0.277107 & 2.032726 & 0.0765 \\
\hline $\mathrm{D}(\operatorname{LEXR}(-1))$ & 0.929104 & 0.275582 & 3.371426 & 0.0098 \\
\hline $\mathrm{D}(\operatorname{LEXR}(-2))$ & 0.536901 & 0.212643 & 2.524891 & 0.0355 \\
\hline
\end{tabular}

Source: Authors computation with E-view 10.0, 2017.

utilize the auto regressive distributed lag (ARDL) to estimate both the short-run and long run coefficients of the model and the result presented in Table 3. The F-bound test result (4.407205) compared with critical peasaran value (2.14 and 3.71) rejects the null hypothesis of no levels of relationship for the $\mathrm{I}(0)$ and I(1) levels relationship (that is, for the variables integrated of order (0) and (1) in the model.

\section{DISSCUSSION}

The result of the auto regressive distributed model (ARDL) shows all the relevant variables. Further analysis of the result (Table 4) shows that external debts stock LEDS(-1), the external reserve, LEXTR(-1), and D(LEDS($3)$ ), have significant positive relationship with economic growth but debt servicing payment $\operatorname{LDSP}(-1)$ has a negative but significant impact on economic growth and domestic debt lag 1, D(LDDS (-1)), has a positive but not significant effect on economic growth (Table 4). This finding is line with the finding of Uzun et al. (2012) who used ARDL model and found that external debt has a positive impact on economic growth. This finding is in tandem with a-priori expectation as external debt entails a foreign exchange inflow to borrowing country and may 
Table 5. Levels equation.

\begin{tabular}{lcccc}
\hline Variable & Coefficient & Std. Error & t-Statistic & Prob. \\
\hline LEDS & 0.267853 & 0.150184 & 1.783497 & 0.1123 \\
LDSP & -0.308343 & 0.148869 & -2.071235 & 0.0721 \\
LEXTR & 0.655586 & 0.227129 & 2.886408 & 0.0203 \\
LDDS & 0.531871 & 0.254065 & 2.093441 & 0.0696 \\
LEXR & -0.402680 & 0.117967 & -3.413510 & 0.0092 \\
Coint Eq $(-1)^{*}$ & -0.708078 & 0.108018 & -6.555169 & 0.0002 \\
\hline
\end{tabular}

Source: Authors computation with E-view 10.0, 2017.

facilitate the acquisition of critical infrastructure. It is at the points of repayment that external debt starts to have toll on the debtor economy especially when the borrowed fund is not investment on viable projects from both economic and social stand point. The result of the conditional error correction regression suggests that external debts stock lag 1 , that is, $\operatorname{LEDS}(-1)$ has a significant direct relationship with economic growth at 1 percent significance level. Specifically a percentage change in the previous period's external debt stock indicates 0.19 percentage change in economic growth holding other variables at constant. The estimated long run coefficient result indicates that all the variables have significant relationship with economic growth except domestic debt stock lag 1.

The analysis of the levels equation estimate shows that though external debts stock indicates no significant relationship with economic growth but external debt service payment reveals a significant negative effect on economic growth (Table 5). A closer observation of the analysis suggests that a percentage change in external debt service payment brings about 0.31 percentage reduction in economic growth holding other variables at constant. In magnitude and direction it could be noted that a percentage debt service payment retards economic growth by 0.31 percent. This therefore implies that the hypothesis that there is no significant relationship between external debt and economic growth in Nigeria cannot be accepted for the study.

There is a significant positive relationship between external reserve and economic growth at 5 percent level of significance. Specifically, a percentage change in external reserves results to 0.66 percentage change in economic growth. This shows that increases in external reserve bring about a corresponding increase in economic growth. It could be further observed that the degree of responsiveness of economic growth to the change in external reserve is inelastic. The result of the estimated parameter for external reserve thus conforms to a priori expectation since it is expected that increases in foreign reserve will help to boost economic activities in the country.

Domestic debt stock indicates a positive but not significant relationship with economic growth at 5 percent significance level.
The estimated exchange rate coefficient indicates a significant inverse relationship with economic growth at 1 percentage significance level. A detailed analysis of the result suggests that a percentage change in exchange rate will result to 0.40 percentage change in economic growth. This could be further explained that exchange rate appreciation could tend to reduce the value and demand for naira currency leading to retarded demand for Nigerian export of goods and services. This therefore conforms to economic theory since foreign exchange rate appreciation against the local currency could tend to retard the level of economic growth.

Hence it could be observed that external debt service payment and exchange rate indicate a significant negative effect on economic growth while external reserve reveals a significant positive impact on economic growth in the long run. These variables therefore constitutes important factors that could determine economic growth and further plays a significant role in determining the variations in real economic growth level over the period considered in this study. The error correction term was correctly signed $(-0.70807 ; p$-value $=$ 0.0002 ), within the magnitude of zero and 1 and statistically significant at 1 percent. This therefore suggests that 71 percent of the imbalances in the system arising from exogenous shocks will be corrected per time. This implies a relatively high speed of systemic adjustment and convergence of the system from the short-run dynamics to the long-run steady state.

\section{CONCLUSION}

This study examined the effect of external debt on economic growth in Nigeria. Gross domestic product was used as a proxy for economic growth which is the dependent variable while external debt stock, external debt service payments, domestic debt, external reserve and exchange rate were the independent variables. External debt stock and external debt service payments were used to capture the external debt burden in Nigeria.

The study adopted the ARDL bound testing to cointegration as an appropriate technique. The result shows that domestic debt lag $1, \mathrm{D}(\operatorname{LDDS}(-1))$, has a negative but significant effect on economic growth. The result of 
the ARDL bound test (Table 4) suggests that external debts stock lag 1 , that is, LEDS $(-1)$ has a significant direct relationship with economic growth at 1 percent significance level. It could also be observed that external debt service payment and exchange rate indicate a significant negative effect on economic growth while external reserve reveals a significant positive impact on economic growth in the long run. By implication external debt is good as long as it fills the saving gap and enhances investment in critical infrastructure but borrowing nations should be very careful in using external debt because repayment usually drains the resources that could be used to maintain and upgrade infrastructures especially when the economy is experiencing regular depreciation of currency in face of inelastic demand and supply conditions as in the case of Nigeria.

\section{RECOMMENDATION}

Based on the above findings, the following recommendations are made:

Firstly, external debts should be contracted solely for economic reasons and not for social or political reasons. When government is increasing her spending based on external debt, they must be meticulous about the sector of the economy where the loan is channeled. Increase in government spending centered on agriculture, manufacturing, entrepreneurship, human capital development and technological innovation will definitely stimulate economic growth and enhance the pace of development. While increase in government spending on the non-productive sector (current consumption) of the economy from external loan will spontaneously crowd out private saving and investment and may depress the economy.

Secondly, Nigeria's debt management office should adequately keep track of the debt payment obligations and the debt to GDP ratio should not be allowed to deteriorate with the argument that it is within acceptable thresh-hold as absorptive capacity is more significant than the standardized ratio in economic management. Government is also expected to formulate public-private sector investment programmes that would emphasize non debt-creating financing option to reduce the burden of foreign debt.

Lastly the Nigerian government should promote a more dynamic exchange management regime which will facilitate greater inflow of foreign exchange into the Nigerian market.

\section{Suggestion}

Further research should be done on the methods through which external debt may be properly managed in order to foster economic growth in Nigeria in the long run.

\section{REFERENCES}

Adejuwon KD, James KS, Soneye OA (2010). "Debt Burden and Nigeria Development". J. Bus. Organ. Dev. 2:102-113.

Adesola WA (2009). "Debt servicing and Economic Growth in Nigeria: An Empirical Investigation" Glob. J. Soc. Sci. (2):1-11.

Ajayi K (2000). "The Feasibility of Democracy in Africa". Dakar: CODESRIA Books.

Akran N (2011). 'Impact of public debt on economic growth of Pakistan' The Pak. Dev. Rev. 50(4):599-615.

Amassoma D (2011). External debt, internal debt and economic growth bound in Nigeria using a causality approach. Curr. Res. J. Soc. Sci. 3(4):320-325.

Amin S (1976). "Unequal Development: An Essay on the Social Formations of Peripheral Capitalism". New York: Monthly Review Press.

Arnone M, Bandiera L, Presbiteno A (2005). External Debt Sustainability: Theory and Empirical Evidence, Retrieved from http://www.unicatt.it/dipartimenti/DISES/allegati/arnoneBandierapresb ite.

Ayadi FS, Ayadi FO (2008). "The Impact of External Debt on Economic Growth: A Comparative Study of Nigeria and South Africa". J. Sustain. Dev. Afr. 10(3):234-264.

Blinder AS (2008). Keynesian Economics. $2^{\text {nd }}$ Edition. The course encyclopedia of economics. File111c:/users/hp/desktop/ph.

Boboye AL, Ojo MO (2012). The Effect of External Debt on Economic Growth and Development in Nigeria, Int. J. Bus. Soc. Sci. 3(12):297304.

Chenery HB, Strout AM (1966). Foreign Assistance and Economic Development, Am. Econ. Rev. 56:679-733.

Dereje AE (2013). The Effect of External DEBT ON Economic Growth: A Panel Data Analysis on the Relationship between External Debt and Economic Growth. Soderston University.

Egbetunde T (2012). "Public Debt and Economic Growth: Evidence from Granger Causality". Am. J. Econ. 2(6): 101-106.

Hunt SD (2007). "Economic growth: should policy focus on investment on dynamic competition?" Eur. Bus. Rev. 19(4):279-291.

Keynes J (1964). The General Theory of Employment, Interest and Money, New York Harkcourt, Brace and World Inc.

Momoh A, Hundeyin T (1999). "Perspectives on Political Economy" in Anifowose, R. \& Enemuo, F. eds Elements of Politics. Lagos, Malthouse Press Limited.

Mundi (2017). www.indexmundi.com-Nigeria :external debt.

Ogbeifun MI (2007). "The politics of external debt relief: Nigeria's unique experience". Afr. J. Stab. Dev. 1(1):79-99.

Oloyede B (2002). "Principles of International Finance". Forthright Educational Publishers, Lagos.

Omoruyi SE (2005). "Debt Burden (Sustainability) Indicators". Presentation Paper at Regional Course on Debt Recording and Statistical Analysis.

Rahman MM, Basher MA, Dey S (2012). "External Debt and Gross domestic Product in Bangladesh": A Co-integration Analysis. Manage. Res. Pract. (4):28-36.

Safadari M, Mehrizi MA (2011). "External debt and Economic growth in Iran". J. Econ. Int. Finan. 3(5):322-327.

Todaro MP (2003). "Economic Development, Eight Low Prize Edition, New Delhi: Pearson Education".

Uzun A, Kabadayi B, Karakoy C, Emsen OS (2012). "The impact of external debt on economic growth in transitional economies." Chin. Bus. Rev. 2(5):491-499. 